\title{
Optimizing Yield and Quality of Canola Cultivars Using Various Potash Levels
}

\author{
Ansaar Ahmed1, Fayaz Ali², Inamullah'1, Amjad Ali², Arif Ullah ${ }^{3}$, Rubina Naz ${ }^{4}$, \\ Amanullah Mahar ${ }^{2,5}$, Shahmir Ali Kalhoro6 \\ ${ }^{1}$ Department of Agronomy, The University of Agriculture, Peshawar, Pakistan \\ ${ }^{2}$ College of Natural Resources and Environment, Northwest A\&F University, Yangling, China \\ ${ }^{3}$ College of Economics and Management, Northwest A\&F University, Yangling, China \\ ${ }^{4}$ Department of Botany, Kohat University of Science \& Technology, Kohat, Pakistan \\ ${ }^{5}$ Centre for Environmental Sciences, University of Sindh, Jamshoro, Pakistan \\ ${ }^{6}$ Faculty of Agriculture, Lasbela University of Agriculture, Water \& Marine Sciences, Lasbela, \\ Pakistan \\ Email: ${ }^{*}$ amjadali@aup.edu.pk
}

Received 19 March 2015; accepted 23 May 2015; published 26 May 2015

Copyright (C) 2015 by authors and Scientific Research Publishing Inc.

This work is licensed under the Creative Commons Attribution International License (CC BY).

http://creativecommons.org/licenses/by/4.0/

(c) () Op Open Access

\section{Abstract}

The response of several canola cultivars to different potassium $(\mathrm{K})$ levels was investigated in terms of various agronomic parameters including yields, oil and protein contents in a trial conducted at The University of Agriculture, Peshawar-Pakistan in Rabi 2010-11. Three cultivars including Bulbul-98, Abaseen-95 and Dure-NIFA, with five levels of potassium i.e. 0, 30, 60, 90 and 120 kg.ha-1 were used in Randomized Complete Block (RCB) design with four replications and factorial arrangement. A larger number of days to $50 \%$ flowering (116.6 days), plant height (203.8 $\mathrm{cm})$, leaf area index (4.4), 1000 grain weight ( $3.5 \mathrm{~g})$, biological yield $\left(13189.3 \mathrm{~kg} \cdot \mathrm{ha}^{-1}\right)$, grain yield $\left(1799.2 \mathrm{~kg} \cdot \mathrm{ha}^{-1}\right)$ and harvest index (13.9\%) were obtained in $\mathrm{K}$ applied plots than the plots where $K$ was not applied. The highest oil $(45.1 \%)$ and protein $(27.7 \%)$ was obtained in plots where $K$ was applied at the rate of 120 and $90 \mathrm{~kg} \cdot \mathrm{ha}^{-1}$, respectively. Among cultivars, Bulbul-98 and Abaseen-95 had higher seed yield and oil percentage. Bulbul-98 had more protein content than Abaseen-95 and Durre-NIFA. On average, cultivars gave higher and at par grain yield at 60,90 and $120 \mathrm{~kg}^{-\mathrm{ha}^{-1}}$. However, they produced higher and at par oil and protein percentage at 90 and $120 \mathrm{~kg} \cdot \mathrm{ha}^{-1}$. Bulbul-98 and Abaseen-95 are recommended for higher grain yield and oil content for general cultivation in Peshawar valley. However, for higher protein content, Bulbul-98 is better. Potassium applied at $60 \mathrm{~kg} \cdot \mathrm{ha}^{-1}$ is recommended for higher grain yield, however, for higher oil and protein content, $\mathrm{K}$ at $90 \mathrm{~kg} \cdot \mathrm{ha}^{-1}$ is recommended.

\footnotetext{
*Corresponding author.
}

How to cite this paper: Ahmed, A., Ali, F., Inamullah, Ali, A., Ullah, A., Naz, R., Mahar, A. and Kalhoro, S.A. (2015) Optimizing Yield and Quality of Canola Cultivars Using Various Potash Levels. American Journal of Plant Sciences, 6, 1233-1242. 
Keywords

Biological Yield, Canola, Potassium, Harvest Index, Protein, Oil

\section{Introduction}

Rapeseed is a prominent affiliate of the family Cruciferae and genus Brassica [1]. Other species of this genus are campestris, nigra, carinata, juncea and oleracea etc. Rapeseed and mustard were grown in Indus Valley at about $300 \mathrm{BC}$ for animals. In $15^{\text {th }}$ century $\mathrm{AD}$, its oil was used for various purposes such as lubrication of machinery [2]. It has a good amount of edible oil but the erucic acid and glucosinolate present in its oil and seed cake, respectively, make it distasteful and toxic for human and animal's health. Due to these substances, Brassica could not get vital place as an oilseed crop until the introduction of canola in 1976 [3]. Erucic acid amount of $2 \%$ in oil and glucosinolates amount less than $30 \mu \cdot \mathrm{mol} \cdot \mathrm{g}^{-1}$ in oil free meal are the safe limits [4]. Decrease in amount of these chemicals in Canada, synthesizes rapeseed the $3^{\text {rd }}$ most important edible oil of the world, preceded by soybean and palm oil respectively [5].

Rapeseed and mustard are grown on a large scale in Pakistan [6]. Its grains output is $812 \mathrm{~kg} \cdot \mathrm{ha}^{-1}$ [7]. This output is smaller than the rapeseed output of other nations in the world. European Union has an average yield of $3500 \mathrm{~kg} \cdot \mathrm{ha}^{-1}$, Canada $3200 \mathrm{~kg} \cdot \mathrm{ha}^{-1}$ and Australia $2000 \mathrm{~kg} \cdot \mathrm{ha}^{-1}$ [8]. The main cause for failure of our farmers to get its highest yield is the use of low yielding varieties and lack of ideal conditions required for the proper growth and development of this crop. Sustainable nutrients management in soil is of major importance which includes type, amount, time and method of fertilizer usage. Higher crop productivity depends upon the time, kind and appropriate amount of fertilization [9]. The application of $\mathrm{K}$ enhances seed yield and seed oil contents in brassica as reported by [10]. It is reported that $\mathrm{K}$ increased the seed oil content of Tower variety of $B$. napus [11]. It is reported that the application of $\mathrm{K}$ along with $\mathrm{N}$ and $\mathrm{P}$ fertilizers improves the seed yield of rapeseed [12]. Potassium is known to increase pest resistance, as well as resistance to diseases and other biotic and abiotic environmental stresses [13]-[15]. Plant tissues contain higher $\mathrm{K}^{+}$ion than other cations. $\mathrm{K}$ regulates effectively many physiological and biochemical processes inside plants [16]. $\mathrm{K}$ affects photosynthesis through ATP formation, regulates $\mathrm{H}_{2} \mathrm{O}$ and $\mathrm{CO}_{2}$ exchange through stomata as an osmoregulator, affects protein synthesis by activating enzyme nitrate reductase and transfers sugar to seeds [17]. Furthermore, it has a strong interaction with Nitrogen. Increase in the uptake of $\mathrm{N}$ has been reported due to increase in K level in barley [18], cowpea [19], cotton [20] and maize [21].

The use of $\mathrm{N}$ and $\mathrm{P}$ fertilizer for agronomic crops is well known, well understood and well practiced but little priority has been given to K for crop husbandry in the past [22]-[25]. In Pakistan, the application of potassium as fertilizer for crop production is negligible and the ratio of $\mathrm{N}$ : $\mathrm{P}$ : $\mathrm{K}$ fertilizer is imbalanced. $\mathrm{K}$ application in Pakistan for agronomic crops is $0.8 \mathrm{~kg} \cdot \mathrm{ha}^{-1}$ while in outside world its mean use is $15 \mathrm{~kg} \cdot \mathrm{ha}^{-1}$ [26]. K reserves are being mined rapidly due to intensive cultivation of field crops. Low response to applied $\mathrm{K}$ is indication of nutrient mining from the soil. About $4 \mathrm{~kg} \cdot \mathrm{ha}^{-1}$ of potassium is removed in cereal grain harvest and about the same leaches down with irrigation and rain water [17]. The reason for low use of $\mathrm{K}$ in agronomic crops in the country may be due to the poor economic status of growers and low return from investment in cereals. As the potassium use is almost negligible, the applied $\mathrm{K}$ to crops sometimes does not get proper response from crops, because applied $\mathrm{K}$ becomes fixed in the clay lattice and low $\mathrm{K}$ application hardly fulfills the soil thirst and yield is badly suffered [16]. The trial under study was, therefore, planted to investigate the outcome of diverse potassium levels on yield and quality of popular canola cultivars in Peshawar valley.

\section{Materials and Methods}

\subsection{Experimental Layout and Design}

A trial was undertaken to find out the effect of various potassium levels on yield and quality of canola cultivars at The University of Agriculture, Peshawar-Pakistan during winter 2010-11. The trial had three canola cultivars (Abaseen-95, Bulbul-98 and Dure-NIFA) and four rates of potassium (0, 30, 60, 90 and $120 \mathrm{~kg} \cdot \mathrm{ha}^{-1}$ ). MOP was used as a source of potash. Factorial combination of cultivars \& potassium levels in an RCB design was used for 
sowing the experiment in four replications. Seeds of improved canola cultivars (Abaseen-95, Bulbul-98 and Dure-NIFA) were sown on $21^{\text {st }}$ October 2010. The plot size was $5 \times 2.1 \mathrm{~m}^{2}$ having row to row distance of $35 \mathrm{~cm}$. Rotavator was used to prepare a soft seedbed. Basal doses of N-P were applied at $80-60 \mathrm{~kg} \cdot \mathrm{ha}^{-1}$ as Urea and DAP, respectively, during seedbed preparation. $50 \%$ of $\mathrm{N}$ was applied each at sowing and at flowering, respectively. All agronomic practices were strictly followed uniformly throughout the growing season for optimum crop growth.

\subsection{Yield Attributes}

The parameters studied were days to 50\% flowering, Plant height, Leaf Area Index (LAI), 1000 grains weight, Biological yield, Grain yield. Harvest index in percent was calculated by using the following formula [8]:

Harvest Index $(\%)=($ Grain yield/Biological yield $) \times 100$.

\subsection{Quality Parameters}

Quality parameters like\% oil and protein content were determined by gathering random grains from each experimental plot. Analysis of the grain samples for oil and proteins content was done employing FOSS Routine near Measurement System (35RP-3752F) at Oilseed Quality Lab of the Crop Breeding Division, Nuclear Institute for Food and Agriculture (NIFA), Peshawar, Pakistan according to the procedure outlined [27].

\subsection{Statistical Analysis}

ANOVA techniques suitable for randomized complete block design [28] were employed to screen the documented data for achieving information regarding the factors.

\section{Results}

\subsection{Days to $50 \%$ Flowering}

Thorough checking of data revealed that cultivars differed from each other in days to $50 \%$ flowering (Table 1). Abaseen-95 and Bulbul-98 took higher and at par number of 116.6 and 116.3 days while Durre-NIFA took 115.2 days to $50 \%$ flowering, respectively. Days to $50 \%$ flowering of cultivars were increased when $\mathrm{K}$ levels was raised. Plants in plots where K was not applied, took minimum number of 115.1 days to $50 \%$ flowering. However, this value was statistically similar with plot where $\mathrm{K}$ was applied at $30 \mathrm{~kg} \cdot \mathrm{ha}^{-1}$ which took 115.5 days. In addition, maximum days to $50 \%$ flowering (116.6 d) was recorded in plot which received $\mathrm{K}$ at 90 or 120 $\mathrm{kg} \cdot \mathrm{ha}^{-1}$. However, it was statistically at par with plots which received $60 \mathrm{~kg} \cdot \mathrm{K}^{\prime} \cdot \mathrm{ha}^{-1}$ which took 116.3 days to $50 \%$ blooming. Non significant Cultivar x K interaction impact was observed on days to $50 \%$ flowering of canola cultivars.

\subsection{Leaf Area Index (LAI)}

It was noted that canola cultivars varied significantly from each other for LAI (Table 2). The highest LAI (4.4) was recorded for Bulbul-98, followed by Abaseen-95 and Dure-NIFA with LAI of 3.7 and 3.2, respectively. LAI increased with $\mathrm{K}$ application as compared to the plots where $\mathrm{K}$ was not applied. At zero level $\mathrm{K}$, minimum LAI (3.4) was recorded which was statistically similar with plots which received 30 and $60 \mathrm{~kg} \cdot \mathrm{K} \cdot \mathrm{ha}^{-1}$. However, LAI significantly increased to 3.9 and 4 with the application of 90 and $120 \mathrm{~kg} \cdot \mathrm{K} \cdot \mathrm{ha}^{-1}$. All cultivars responded in similar pattern to increase in $\mathrm{K}$ level and thus no significant cultivar x $\mathrm{K}$ interaction impact was observed on LAI.

\subsection{Plant Height}

Statistical analysis showed that cultivars differ significantly in plant height from each other (Table 3). Taller plants having heights of $203.8 \mathrm{~cm}$ and $203.6 \mathrm{~cm}$ were recorded for cultivars Abaseen-95 and Durre-NIFA, respectively, while Bulbul-98 recorded shorter plants $(174.4 \mathrm{~cm})$. Plant height was enhanced with the K application. The lowest plant height $(182.1 \mathrm{~cm})$ was observed in control. However, significantly taller plants having heights of 186.4, 197.8, 207.9 and $195.5 \mathrm{~cm}$ were observed in plots which received 30, 60, 90 and $120 \mathrm{~kg} \cdot \mathrm{ha}^{-1} \mathrm{~K}$, respectively. Furthermore, plant height was statistically non significant in plots which received 60 and 120 $\mathrm{kg} \cdot \mathrm{K} \cdot \mathrm{ha}^{-1}$. No significant cultivar x K interaction effect was observed on plant height of canola cultivars. 
Table 1. Days to $50 \%$ flowering of various canola cultivars as affected by various K levels.

\begin{tabular}{ccccc}
\hline $\begin{array}{c}\text { K levels } \\
\left(\mathbf{k g}^{-\mathbf{h a}} \mathbf{~}^{\mathbf{1}} \mathbf{)}\right.\end{array}$ & Bulbul-98 & Abaseen-95 & Durre-NIFA & Mean \\
\cline { 2 - 4 } & 115.5 & 115.5 & 114.3 & $115.1 \mathrm{c}$ \\
30 & 115.8 & 116.0 & 114.8 & $115.5 \mathrm{bc}$ \\
60 & 116.3 & 117.0 & 115.5 & $116.3 \mathrm{ab}$ \\
90 & 116.8 & 117.3 & 115.8 & $116.6 \mathrm{a}$ \\
120 & 117.0 & 117.3 & 115.5 & $116.6 \mathrm{a}$ \\
\hline
\end{tabular}

LSD value ( $\mathrm{P} \leq 0.05$ ) for cultivars: 0.69 . LSD value $(\mathrm{P} \leq 0.05)$ for potassium: 0.89 . Means in similar category with different alphabets differ significantly.

Table 2. Leaf area index of various canola cultivars as affected by various K levels.

\begin{tabular}{|c|c|c|c|c|}
\hline \multirow{2}{*}{$\begin{array}{l}\text { K levels } \\
\left(\mathrm{kg} \cdot \mathrm{ha}^{-1}\right)\end{array}$} & \multicolumn{3}{|c|}{ Cultivars } & \multirow[t]{2}{*}{ Mean } \\
\hline & Bulbul-98 & Abaseen-95 & Durre-NIFA & \\
\hline 0 & 4.1 & 3.3 & 2.9 & $3.4 \mathrm{c}$ \\
\hline 30 & 4.3 & 3.5 & 3.0 & $3.6 \mathrm{bc}$ \\
\hline 60 & 4.5 & 3.7 & 3.2 & 3.8ab \\
\hline 90 & 4.5 & 3.8 & 3.3 & 3.9a \\
\hline 120 & 4.7 & 3.9 & 3.4 & $4.0 \mathrm{a}$ \\
\hline Mean & $4.4 \mathrm{a}$ & $3.7 \mathrm{~b}$ & $3.2 \mathrm{c}$ & \\
\hline
\end{tabular}

LSD value $(\mathrm{P}<0.05)$ for cultivar: 0.16. LSD value $(\mathrm{P}<0.05)$ for potassium: 0.20 . Means in similar category with different alphabets differ significantly.

Table 3. Plant height $(\mathrm{cm})$ of various canola cultivars as affected by various potassium levels.

\begin{tabular}{ccccc}
\hline $\begin{array}{c}\text { K levels } \\
\left(\mathbf{k g}^{-h^{-1}} \mathbf{)}\right.\end{array}$ & Bulbul-98 & Cultivars & Mean \\
\cline { 2 - 4 } 0 & 163.2 & 188.7 & 194.4 & $182.1 \mathrm{~d}$ \\
30 & 167.6 & 194.3 & 197.3 & $186.4 \mathrm{c}$ \\
60 & 175.4 & 210.5 & 207.6 & $197.8 \mathrm{~b}$ \\
90 & 188.6 & 221.2 & 214.0 & $207.9 \mathrm{a}$ \\
120 & 177.2 & 204.5 & 205.0 & $195.5 \mathrm{~b}$ \\
\hline
\end{tabular}

LSD value ( $\mathrm{P} \leq 0.05)$ for cultivars: 2.40. LSD value $(\mathrm{P} \leq 0.05)$ for potassium: 3.10. Means in similar category with dissimilar alphabets differ significantly.

\subsection{Seed Oil Content (\%)}

It was noted that oil percentage of the seed was influenced by cultivars and $\mathrm{K}$ application (Table 4). DurreNIFA produced greater oil content (44.3\%) followed by Bulbul-98 and Abaseen-95, which produced significantly lower oil content (43.6\%). Oil content was significantly increased with higher K application rates. Plots where $\mathrm{K}$ was not applied or where $\mathrm{K}$ was applied at $30 \mathrm{~kg} \cdot \mathrm{ha}^{-1}$ produced low oil content of (42.3\%). Oil content 
(44.3\%) produced in plots which received $\mathrm{K}$ at $60 \mathrm{~kg} \cdot \mathrm{ha}^{-1}$. Significantly higher oil contents of $45.1 \%$ and $45 \%$ were produced in plots which received $\mathrm{K}$ at 120 and $90 \mathrm{~kg} \cdot \mathrm{ha}^{-1}$, respectively. Cultivar $\times \mathrm{K}$ interaction did not significantly affect oil content of canola cultivars.

\subsection{Protein Content (\%)}

Perusal of the data regarding protein content of canola cultivars indicated that cultivars, $\mathrm{K}$ application and the interaction of cultivar x K has significant effect on protein content of canola (Table 5). The contents of proteins augmented with increase in $\mathrm{K}$ application level. The higher protein content (27.7\%) was recorded with 90 and $120 \mathrm{~kg} \cdot \mathrm{ha}^{-1} \mathrm{~K}$. With zero K application, the lowest (24.1\%) protein content was obtained, which was statistically different from the plots which received 30 and $60 \mathrm{~kg} \cdot \mathrm{ha}^{-1} \mathrm{~K}$. Difference in protein content of cultivars was also significant. Higher protein content (26.7\%) was produced by Bulbul-98 followed by Abaseen-95 and DurreNIFA (26.1\%) and (25.8\%), respectively.

Canola cultivars responded differently in protein content with change in the level of $\mathrm{K}$. All the three cultivars showed lower protein content with zero potassium. In K control plots, the protein content of Durre-NIFA was smaller than Abaseen-95 and Bulbul-98. With boost in Potash level from zero to $30 \mathrm{~kg} \cdot \mathrm{ha}^{-1}$, mild raise was observed in protein content of all the three cultivars. However, with further rise in $\mathrm{K}$ level up to $60 \mathrm{~kg} \cdot \mathrm{ha}^{-1}$, a very sharp boost was observed in protein content of Durre-NIFA, surpassing the protein content of Abaseen-95. Increase in protein content of Bulbul-98 was also sharper. With increase in $\mathrm{K}$ level from 60 to $90 \mathrm{~kg} \cdot \mathrm{ha}^{-1}$, increase in protein content of Abaseen-95 was sharper surpassing the protein content of Durre-NIFA. With further raise in $\mathrm{K}$ content from 90 to $120 \mathrm{~kg} \cdot \mathrm{ha}^{-1}$, there was a very small increase in protein content of all the three cultivars. At $120 \mathrm{~kg} \cdot \mathrm{K} \cdot \mathrm{ha}^{-1}$, protein content in the cultivars was almost the same.

Table 4. Seed oil content (\%) of various canola cultivars as affected by various $\mathrm{K}$ levels.

\begin{tabular}{|ccccc}
\hline $\begin{array}{c}\text { K levels } \\
\left(\mathbf{k g}^{-1} \mathbf{h a}^{-1}\right)\end{array}$ & Bulbul-98 & Abaseen-95 & Durre-NIFA & Mean \\
\cline { 2 - 5 } & 41.9 & 42.1 & 42.9 & $42.3 \mathrm{c}$ \\
30 & 42.5 & 41.9 & 42.5 & $42.3 \mathrm{c}$ \\
60 & 44.0 & 44.3 & 44.7 & $44.3 \mathrm{~b}$ \\
90 & 44.5 & 45.0 & 45.6 & $45.0 \mathrm{a}$ \\
120 & 45.0 & 44.9 & 45.6 & $45.1 \mathrm{a}$ \\
\hline
\end{tabular}

LSD value $(\mathrm{P} \leq 0.05)$ for cultivar: 0.51 . LSD value $(\mathrm{P} \leq 0.05)$ for potassium: 0.66 . Means in similar category with different alphabets differ significantly.

Table 5. Seed protein content (\%) of various canola cultivars as affected by various K levels.

\begin{tabular}{|c|c|c|c|c|}
\hline \multirow{2}{*}{$\begin{array}{l}\text { K levels } \\
\left(\mathrm{kg}^{\prime} \mathrm{ha}^{-1}\right)\end{array}$} & \multicolumn{3}{|c|}{ Cultivars } & \multirow[t]{2}{*}{ Mean } \\
\hline & Bulbul-98 & Abaseen-95 & Durre-NIFA & \\
\hline 0 & 24.8 & 24.3 & 23.2 & 24.1d \\
\hline 30 & 25.6 & 25.4 & 23.8 & $24.9 \mathrm{c}$ \\
\hline 60 & 27.3 & 25.6 & 27.4 & $26.8 b$ \\
\hline 90 & 27.9 & 27.8 & 27.3 & $27.7 \mathrm{a}$ \\
\hline 120 & 27.9 & 27.6 & 27.5 & $27.7 \mathrm{a}$ \\
\hline Mean & $26.7 \mathrm{a}$ & $26.1 \mathrm{~b}$ & $25.8 \mathrm{~b}$ & \\
\hline
\end{tabular}

LSD value $(P \leq 0.05)$ for cultivars: 0.59 . LSD value $(P \leq 0.05)$ for potassium: 0.76 . LSD value $(P \leq 0.05)$ for cultivar $x$ potassium: 1.31 . Means in similar category with dissimilar alphabets differ significantly. 


\subsection{Thousand Grain Weight}

Analysis of variance exhibited significant differences among canola cultivars for thousand grain weight (Table 6). Mean values of thousand grains weight of the cultivars revealed that the maximum thousand grain weight was recorded for Bulbul-98 (3.5 g) followed by Abaseen-95 (3.4 g) and Durre-NIFA (3.3 g), respectively. Thousand grains weight was significantly increased with increase in $\mathrm{K}$ level. Plots where $\mathrm{K}$ was not applied produced minimum thousand grains weight of $3.0 \mathrm{~g}$. However, significant increase was observed in plots where $\mathrm{K}$ was applied at the rate of $30,60,90$ and $120 \mathrm{~kg} \cdot \mathrm{ha}^{-1}$ which gave 3.3, 3.5, 3.7 and $3.6 \mathrm{~g}$, respectively. All cultivars responded in similar pattern to the increase in $\mathrm{K}$ levels and there was no significant cultivar $\mathrm{x} \mathrm{K}$ interaction impact on thousand grain weight of canola cultivars.

\subsection{Biological Yield (BY)}

Significant differences for biological yield (BY) were recorded among different canola cultivars (Table 7). BY produced by Abaseen-95 (13189.3 $\mathrm{kg} \cdot \mathrm{ha}^{-1}$ ) was higher than Bulbul-98 $\left(12645.4 \mathrm{~kg} \cdot \mathrm{ha}^{-1}\right)$ and Durre-NIFA $\left(8189.0 \mathrm{~kg} \cdot \mathrm{ha}^{-1}\right)$. BY augmented with enhancement in K application rates. Minimum BY of $11047.3 \mathrm{~kg} \cdot \mathrm{ha}^{-1} \mathrm{was}$ formed in plots where no $\mathrm{K}$ was applied. Significant increase in biological yield was observed in plots receiving $\mathrm{K}$ at 30 and $60 \mathrm{~kg} \cdot \mathrm{ha}^{-1}$ which produced 11288.8 and $11468.4 \mathrm{~kg} \cdot \mathrm{ha}^{-1}$, respectively. Biological yield obtained with $\mathrm{K}$ at $60 \mathrm{~kg} \cdot \mathrm{ha}^{-1}$ was statistically at par with BY produced in plots which received $\mathrm{K}$ at 90 and $120 \mathrm{~kg} \cdot \mathrm{ha}^{-1}$. No significant differences were observed in BY produced by cultivars in interaction with K.

\subsection{Grain Yield}

It was observed that cultivars differed from one another in grain yield (Table 8). Mean values of grain yield of

Table 6. Thousand grain weight (g) of various canola cultivars as affected by various $\mathrm{K}$ levels.

\begin{tabular}{|c|c|c|c|c|}
\hline \multirow{2}{*}{$\begin{array}{l}\text { K levels } \\
\left(\mathrm{kg}^{\prime} \mathrm{ha}^{-1}\right)\end{array}$} & \multicolumn{3}{|c|}{ Cultivars } & \multirow[t]{2}{*}{ Mean } \\
\hline & Bulbul-98 & Abaseen-95 & Durre-NIFA & \\
\hline 0 & 3.3 & 2.9 & 2.7 & $3.0 \mathrm{~d}$ \\
\hline 30 & 3.5 & 3.2 & 3.2 & $3.3 \mathrm{c}$ \\
\hline 60 & 3.6 & 3.4 & 3.4 & $3.5 b$ \\
\hline 90 & 3.7 & 3.8 & 3.6 & $3.7 \mathrm{a}$ \\
\hline 120 & 3.6 & 3.8 & 3.5 & 3.6ab \\
\hline Mean & 3.5 a & $3.4 \mathrm{ab}$ & $3.3 \mathrm{~b}$ & \\
\hline
\end{tabular}

LSD value $(\mathrm{P} \leq 0.05)$ for cultivar: 0.13 . LSD value $(\mathrm{P} \leq 0.05)$ for potassium: 0.17 . Means in similar category with different alphabets differ significantly.

Table 7. Biological yield $\left(\mathrm{kg} \cdot \mathrm{ha}^{-1}\right)$ of canola cultivars as influenced by various K levels.

\begin{tabular}{ccccc}
\hline $\begin{array}{c}\text { K levels } \\
\left(\mathbf{k g}^{-h^{-1}} \mathbf{)}\right.\end{array}$ & Bulbul-98 & Cultivars & Mean \\
\cline { 2 - 4 } & 12329.9 & 12889.5 & 7922.5 & $11047.3 \mathrm{c}$ \\
30 & 12598.2 & 13147.7 & 8120.3 & $11288.8 \mathrm{~b}$ \\
60 & 12777.1 & 13270.2 & 8357.8 & $11468.4 \mathrm{a}$ \\
90 & 12770.0 & 13302.0 & 8299.9 & $11457.3 \mathrm{a}$ \\
120 & 12751.8 & 13337.3 & 8244.4 & $11444.5 \mathrm{ab}$ \\
\hline
\end{tabular}

LSD value $(\mathrm{P} \leq 0.05)$ for cultivar: 120.7. LSD value $(\mathrm{P} \leq 0.05)$ for potassium: 155.8. Means in the similar category with dissimilar alphabets differ significantly. 
Table 8. Grain yield $\left(\mathrm{kg} \cdot \mathrm{ha}^{-1}\right)$ of various canola cultivars influenced by various K levels.

\begin{tabular}{ccccc}
\hline $\begin{array}{c}\text { K levels } \\
\left(\mathbf{k g}^{-1} \mathbf{)}\right)\end{array}$ & Bulbul-98 & Cultivars & Mean \\
\cline { 2 - 4 } & 1506.9 & 1527.4 & Durre-NIFA & $1288.7 \mathrm{c}$ \\
\hline 0 & 1612.7 & 1666.5 & 1031.8 & $1447.8 \mathrm{~b}$ \\
60 & 1884.1 & 1920.6 & 1155.0 & $1653.2 \mathrm{a}$ \\
90 & 1906.6 & 1940.7 & 1164.7 & $1670.7 \mathrm{a}$ \\
120 & 1885.9 & 1940.7 & 1164.7 & $1663.8 \mathrm{a}$ \\
\hline
\end{tabular}

LSD value $(\mathrm{P} \leq 0.05)$ for cultivar: 44.09. LSD value $(\mathrm{P} \leq 0.05)$ for potassium: 56.92 . Means in similar category with different alphabets differ significantly.

canola cultivars depicted that maximum grain yield was recorded for Abaseen-95 (1799.2 $\left.\mathrm{kg} \cdot \mathrm{ha}^{-1}\right) \mathrm{with}^{\mathrm{at}} \mathrm{par}$ values for Bulbul-98 (1759.2 $\mathrm{kg} \cdot \mathrm{ha}^{-1}$ ) followed by significantly lower grain yield recorded for Durre-NIFA $\left(1076.1 \mathrm{~kg} \cdot \mathrm{ha}^{-1}\right)$. Grain yield was improved with increase in $\mathrm{K}$ level. Lowest grains output $\left(1288.7 \mathrm{~kg} \cdot \mathrm{ha}^{-1}\right) \mathrm{was}$ quantified with zero K. However, significant increase in grains output was recorded with $30 \mathrm{~kg} \cdot \mathrm{ha}^{-1} \mathrm{~K}$ which gave grains produce of $1447.8 \mathrm{~kg} \cdot \mathrm{ha}^{-1}$. Further, larger boost in grain yield was seen when level of $\mathrm{K}$ raised to 60 $\mathrm{kg} \cdot \mathrm{ha}^{-1}$ which recorded $1653.2 \mathrm{~kg} \cdot \mathrm{ha}^{-1}$ grain produced. In addition, grains output obtained at $60 \mathrm{~kg} \cdot \mathrm{ha}^{-1} \mathrm{~K}$ was statistically not different from grain yield produced in plots which received $\mathrm{K}$ at 90 and $120 \mathrm{~kg} \cdot \mathrm{ha}^{-1}$. The interaction of cultivar $\mathrm{x} \mathrm{K}$ was found to have no significant impact on grain yield of canola cultivars.

\subsection{Harvest Index (HI)}

Canola cultivars varied significantly from each other in harvest index (Table 9). Maximum harvest index was recorded for Bulbul-98 (13.9\%) followed by Abaseen-95 (13.7\%) and Durre-NIFA (13.1\%). Harvest index increased when K application rate was increased. Minimum harvest index (11.5\%) was observed in plots where K was not applied. However, significant increase in HI $(12.9 \%)$ was noted at $30 \mathrm{~kg} \cdot \mathrm{ha}^{-1}$. With more boost in potash application rate to $60 \mathrm{~kg} \cdot \mathrm{ha}^{-1}$, the HI was raised to $14.3 \%$. HI recorded with $60 \mathrm{~kg}^{-h^{-1}} \mathrm{~K}$ was not significantly different from the harvest indices recorded in plots which received $\mathrm{K}$ at 90 and $120 \mathrm{~kg} \cdot \mathrm{ha}^{-1}$. No significant effect of the interaction of cultivar $\mathrm{x} \mathrm{K}$ on the harvest indices of canola cultivars.

\section{Discussion}

The outcome given in the results is concisely discussed in the succeeding lines.

Days taken by 50\% flowering were notably influenced by $\mathrm{K}$ application and cultivars but were non-significantly affected by cultivar x K interaction. Significantly more days to flowering was recorded in the K application plots than the plots where $\mathrm{K}$ was not applied because significant interactions have been reported between $\mathrm{N}$ \& K for higher yield and quality in cotton [20]. Early maturity was observed in Durre-NIFA as compared to Abaseen-95 and Bulbul-98. The differentiation in the phonological outlook of the cultivars may be due to the difference in the genetic makeup of the species. It is found uppermost heritability (0.903) maturity duration [29] and 0.662 for flowering time. Our results were similar with the findings of [30].

Different levels of K significantly affected plant height. Plant height was increased with increasing $\mathrm{K}$ rates. Durre-NIFA produced taller plants as compared to Abaseen-95 and Bulbul-98. It is declared that K application increases plant height in canola [6].

Crop production is the practical means of trapping solar energy and converting it into food and other useable materials. Crop production strategies are usually designed to exploit light interception by attaining absolute ground cover. LAI suggest leaf area ratio over ground area engaged by the crop. A LAI of 3 - 5 is usually necessary for maximum dry matter production of most cultivated crops. K levels significantly affected leaf area index of canola. Comparing the mean values for K levels, it was found that leaf area index increased as $\mathrm{K}$ level increases and the higher LAI were exhibited by the plots which received higher K. Maximum leaf area index 
Table 9. Harvest index (\%) of various canola cultivars as affected by various K levels.

\begin{tabular}{ccccc}
\hline $\begin{array}{c}\text { K levels } \\
\left(\mathbf{k g}^{-1} \mathbf{h a}^{-1}\right)\end{array}$ & Bulbul-98 & Cultivars & Mean \\
\cline { 2 - 5 } & 12.2 & 11.9 & Durre-NIFA & 10.5 \\
30 & 12.8 & 12.7 & 13.1 & $12.9 \mathrm{c}$ \\
60 & 14.8 & 14.4 & 13.8 & $14.3 \mathrm{a}$ \\
90 & 14.8 & 14.8 & 14.2 & $14.6 \mathrm{a}$ \\
120 & 15.0 & 14.6 & $13.1 \mathrm{~b}$ & $14.6 \mathrm{a}$ \\
\hline
\end{tabular}

LSD value $(\mathrm{P} \leq 0.05)$ for cultivar: 0.37 . LSD value $(\mathrm{P} \leq 0.05)$ for potassium: 0.48 . Means in similar category with dissimilar alphabets differ significantly.

was recorded by Bulbul-98. Above findings are comparable to those of [30] who documented LAI different for various canola cultivars.

Grain heaviness has a bearing on final productivity of any crop plant. Cultivars and K application had a significant influence on 1000-grain weight of canola. Bulbul-98 produced heavier grains than Abaseen-95 and Durre-NIFA. Our results are in compliance with the work of [6], who described that grain mass improved as K rates maximized. The highest 1000-grain weight was recorded with high potassium levels. The lowest value of 1000-grain weight was noted in plots with zero K applied (control). The variation in mean grain weights were normally related to a short period between anthesis and maturity. At this point, availability of assimilates to the seeds plays a vital role in the growth of seed and possibly plants with greater supplies of nutrients than low nutrition condition [31]. The reason for the conflict could be due to the variation in the genetic behavior and nutrient uptake of cultivars. It is described that a positive effect on seeds pod ${ }^{-1}$, siliques plant ${ }^{-1}$ and weight of 1000 seeds heaviness on total seed yield of rapeseed/mustard cultivars [32]

Biological yield is collective harvest and mostly depends upon type, nutrition and season of developing. Canola cultivars \& K supply has a significant effect on biological yield. The maximum biological yield was recorded for Abaseen-95. A reason can be its leafy nature. It is reported that K and S amplified biological yield in Brassica specie. Generally due to fertilizer application, greater than before TDM was noticed [33]. These results are similar to those of [34] who reported that increasing rates of $\mathrm{K}$ increased the dry matter production of canola.

Cultivars and different levels of $\mathrm{K}$ had significant effect on the grain yield. Abaseen-95 produced the highest grain yield followed by Bulbul-98 and Durre-NIFA. Plots with zero level of K showed the lowest seed yield which increased with increasing level of $\mathrm{K}$. The higher grain yield was probably due to increased growth under sufficient amount of macro-nutrient available in soil. The end result are concordant to that of [35] who declared that seed biomass increased in response to increasing $\mathrm{K}$ rates.

Cultivars and $\mathrm{K}$ application had significant influence on harvest index of canola. Comparing different $\mathrm{K}$ levels it was observed that plots without $\mathrm{K} \cdot$ had minimum $\mathrm{HI}$ while the plots that received $\mathrm{K}$ had higher harvest index. These results are supported by [12] who reported that increasing rate of fertilizer application increased HI. HI showed positive relationship with increase in seed yield. It is explained that a direct and substantial relation between grain biomass and $\mathrm{HI}$ [29].

Oil percentage is normally a genotypic property but the nurture also affects it qualitatively and quantitatively. It significantly affected by K application and cultivars. Durre-NIFA gave higher oil content than others. The increase in oil content confirmed the findings of [33] who found that $\mathrm{K}$ application increase oil content in mustard.

Seed protein content showed a significant response to cultivars and K supply. Bulbul-98 produced the highest protein content. $\mathrm{K}$ application increased the protein contents of canola seed. The protein content increase with the $\mathrm{K}$ application confirmed the findings of [36], who explained the relation between $\mathrm{K}$ and protein contents. Our findings are similar with that of [37] who explained that nitrogen and potassium applications increased protein content.

\section{Conclusion}

The response of several canola cultivars to different potassium levels was investigated in terms of various agro- 
nomic parameters including yields, oil and protein contents in a trial conducted. Three cultivars including Bulbul-98, Abaseen-95 and Dure-NIFA, with four rates of potassium i.e. 0, 30, 60, 90 and $120 \mathrm{~kg} \cdot \mathrm{ha}^{-1}$ were used. Cultivars responded positively to $\mathrm{K}$ fertilization for yield, seed quality and most of the other parameters. Larger number of days to $50 \%$ flowering (116.6 days), plant height $(203.8 \mathrm{~cm})$, leaf area index (4.4), 1000 grain weight (3.5 g), biological yield (13189.3 $\left.\mathrm{kg} \cdot \mathrm{ha}^{-1}\right)$, grain yield $\left(1799.2 \mathrm{~kg} \cdot \mathrm{ha}^{-1}\right)$ and harvest index (13.9\%) were obtained in $\mathrm{K}$ applied plots than the plots where $\mathrm{K}$ was not applied. The highest oil (45.1\%) and protein (27.7\%) was obtained in plots where $\mathrm{K}$ was applied at 120 and $90 \mathrm{~kg} \cdot \mathrm{ha}^{-1}$, respectively. Among cultivars, Bulbul-98 and Abaseen-95 had higher seed yield and oil percentage. Bulbul-98 had more protein content than Abaseen-95 and Durre-NIFA. On an average, cultivars gave higher and at par grain yield at 60,90 and $120 \mathrm{~kg}^{-1} \mathrm{ha}^{-1}$. However, they produced higher and at par oil and protein percentage at 90 and $120 \mathrm{~kg} \cdot \mathrm{ha}^{-1}$. Bulbul-98 and Abaseen-95 are recommended for higher grain yield and oil content for general cultivation in Peshawar valley. However, for higher protein content, Bulbul-98 is better. Potassium at the rate of $60 \mathrm{~kg} \cdot \mathrm{ha}^{-1}$ is recommended for higher grain yield, however, for higher oil and protein content, $\mathrm{K}$ at the rate of $90 \mathrm{~kg} \cdot \mathrm{ha}^{-1}$ is recommended.

\section{References}

[1] Weiss, E.A. (1983) Rapeseed. In Oilseed Crops. Longman Group, New York. pp. 161-215. Reported in Crop Prod. Book under the Title Oilseed Crops, p. 389.

[2] Holmes, M.R.J. (1980) Nitrogen in Nutrition of the Oilseed Rape Crop. Applied Science Publishers, Barking Essex, 21-67.

[3] Muhammad, S. Khalil, I.A. and Khan, S. (1991) Fatty Acid Composition of Rape and Mustard Oilseed Cultivars. Science Khyber, 4, 29-36.

[4] Grombacher, A. and Nelson, L. (1992) Canola Production. A University of Nebraska Neb Guide Publication, No. G921076-A. Cooperative Extension, Institute of Agriculture and Natural Resources, University of Nebraska-Lincoln.

[5] Downey, R.K. and Rimmer, S.R. (1993) Agronomic Improvement in Oilseed brassica. Advances in Agronomy, 50, 166. http://dx.doi.org/10.1016/S0065-2113(08)60831-7

[6] Khan, A.H., Khalil, I.A. and Shah, H. (2004) Nutritional Yield and Oil Quality of Canola Cultivars Grown in NWFP. Sarhad Journal of Agriculture, 20, 287-290.

[7] MINFAL (2009) Agriculture Statistics of Pakistan, Ministry of Food, Agriculture and Livestock. Government of Pakistan, Islamabad.

[8] Reddy, S.R. (2004) Principles of Crop Production. 2nd Edition, Kalyani Publishers, New Delhi, 46 p.

[9] Jan, M.T. and Khan, S. (2000) Response of Wheat Yield Components of N-Fertilizer Their Levels and Application Time. Pakistan Journal of Biological Sciences, 3, 1227-1230. http://dx.doi.org/10.3923/pjbs.2000.1227.1230

[10] Ghosh, D.C., Panda, P.K. and Sahoo, P.M. (1995) Response of Rainfall Rapeseed (Brassica compestris) to NPK. Indian Journal of Agricultural Research, 29, 5-9.

[11] Kuo, N.C. and Chen, H. (1980) Response of Agronomic Characters, Seed Yield, Oil Content and Fatty Acid Composition of Rape Seed to NPK Fertilizer Treatments. Journal of the Agricultural Association of China, 11, 23-35.

[12] Kandil, A.A. (1983) Preliminary Study on the Effect of NPK Fertilization on Oil Seed Rape (Brassica napus L.) in Egypt. Proceedings of the 6th International Rapeseed Conference, Paris, 17-19 May 1983, 296.

[13] Zafar, Z.U. and Athar, H.R. (2013) Reducing Disease Incidence of Cotton Leaf Curl Virus (Clcuv) in Cotton (Gossypium hirsutum L.) by Potassium Supplementation. Pakistan Journal of Botany, 45, 1029-1038.

[14] Prabhu, A.S., Fageria, N.K., Huber, D.M. and Rodrigues, F.A. (2007) Potassium and Plant Disease. In: Datnoff, L.E., Elmer, W.H. and Huber, D.M., Eds., Mineral Nutrition and Plant Disease, The American. Phytopathological Society Press, Saint Paul, 57-78.

[15] Reuveni, R. and Reuveni, M. (1998) Foliar-Fertilizer Therapy—A Concept in Integrated Pest Management. Crop Protection, 17, 111-118. http://dx.doi.org/10.1016/S0261-2194(97)00108-7

[16] Bajwa, M.I. and Rehman, F. (1996) Soil and Fertilizer Potassium. In: Bashir, E. and Bantal, R., Eds., Soil Science, NBF, Islamabad, 317.

[17] Wallace, L. (2001) Sustaining Potassium Reserves to Enhance Crops Yields. Farming Ahead, 40-41.

[18] Armstrong, D.I. (1998) Potassium Interactions with Other Nutrients. Better Crops, 28, 12-14.

[19] Geetha, V. and Varughese, K. (2001) Response of Vegetable Cowpea to Nitrogen and Potassium under Varying Methods of Irrigation. Journal of Tropical Agriculture, 39, 111-113.

[20] Hassan, Z. and Arshad, M. (2010) Cotton Growth under Potassium Deficiency Stress Is Influenced by Photosynthetic 
Apparatus and Root System. Pakistan Journal of Botany, 42, 917-925.

[21] Nawaz, I., Zia-ul-hassan, Ranjha, A.M. and Arshad, M. (2006) Exploiting Genotypic Variation among Fifteen Maize Genotypes of Pakistan for Potassium Uptake and Use Efficiency in Solution Culture. Pakistan Journal of Botany, 38, 1689-1696.

[22] Elgharably, A. (2011) Wheat Response to Combined Application of Nitrogen and Phosphorus in a Saline Sandy Loam Soil. Soil Science and Plant Nutrition, 57, 396-402. http://dx.doi.org/10.1080/00380768.2011.582588

[23] Oad, F.C., Naqi Shah, A., Jamro, G.H. and Samo, H.A. (2003) Effect of Nitrogen and Phosphorus Levels on Yield Contributing Parameters of Canola (Brassica napus). Journal of Applied Sciences, 3, 167-169. http://dx.doi.org/10.3923/jas.2003.167.169

[24] Brennan, R.F. (1992) Effect of Superphosphate and Nitrogen on Yield and Take-All of Wheat. Fertilizer Research, 31, 43-49.

[25] Sangakkara, U.R. and Cho, C.M. (1987) Effect of $\mathrm{NH}_{4}{ }^{+}$Nitrogen on Phosphorus Uptake by Canola, Lentils, Soybeans and Wheat. Journal of Agronomy and Crop Science, 159, 199-201. http://dx.doi.org/10.1111/j.1439-037X.1987.tb00086.x

[26] MINFAL (2007) Agricultural Statistics of Pakistan 2006-07. Ministry of Food, Agriculture and Live Stock, Government of Pakistan, Islamabad.

[27] Daun, J.K., Clear, K.M. and Williams, P. (1994) Comparison of Three Whole Seed near Infrared Analyzers for Measuring Quality Components of Canola Seed. Journal of the American Oil Chemists' Society, 71, 1063-1068. http://dx.doi.org/10.1007/BF02675897

[28] Steel, R.G.D. and Torrie, J.H. (1980) Principles and Procedures of Statistics: A Biometrical Approach. 2nd Edition, McGraw Hill Book Co., New York.

[29] Ali, N., Javidfar, F., Elmira, J.K. and Mirza, M.Y. (2003) Relationship among Yield Components and Selection Criteria for Yield Improvement in Winter Rapeseed. Pakistan Journal of Botany, 35, 167-174.

[30] Sultana, S., Rahul, A.K.M. and Hasamuzzaman, M. (2007) Growth and Yield of Rapeseed (Brassica compestris L.) Cultivars as Affected by Level of Irrigations. Journal of Asian Scientific Research, 4, 34-39.

[31] Scott, R.K., Ogunremi, E.A., Ivins, J.D. and Mendham, N.J. (1973) The Effect of Fertilizers and Harvest Date on Growth and Yield of Oil Seed Rape Sown in Autumn and Spring. The Journal of Agricultural Science, 81, 287-293.

[32] Tuncturk, M. and Ciftici, V. (2007) Relationship between Yield and Some Yield Components in Rapeseed (B. napus) Cultivars by Using Correlation and Path Analysis. Pakistan Journal of Botany, 39, 81-84.

[33] Misras, K. (2003) Effect of S and K on Yield, Nutrient Uptake and Quality Characteristics of Mustard (B. juncea L.) in Kanpur. Journal of the Indian Society of Soil Science, 51, 544-548.

[34] Munir, M. and McNeilly, T. (1987) Dry Matter Accumulation, Height and Seed Yield in Spring and Summer Rape as Affected by Fertilizers and Spacing. Pakistan Journal of Agricultural Research, 8, 143-149.

[35] Ghosh, S.K., Tarafdar, P.K. and Mukhopadhyay, A.K. (1993) Response of Potassium to Mustard (B-9) in Soils under Different K Status. Indian Agriculture, 37, 199-203.

[36] Khan, M.A. (2004) Intra Specific Variation and the Role of K for Drought Tolerance in Oilseed Rape. Ph.D. Thesis, University of Arid Agriculture, Rawalpindi.

[37] Nordestgaard, A., Augustinussen E. and Flengmark. P. (1984) Influence of Nitrogen and Potassium Fertilizers on Seed Quality of Winter Oilseed Rape. Tiddsskrift for Planteavl, 88, 327-341. Field Crop Abstracts, 38(8): 4571; 1985. 